\title{
The Ideological Struggle of Multicultural Nationalism: Cultural Identity in the 2014 Malaysian Top-Grossing Movie The Journey
}

\author{
Wang Changsong ${ }^{1}$, and Chen Yiming ${ }^{2, *}$ \\ ${ }^{1}$ Xiamen University Malaysia, 43900, Kuala Lumpur, Malaysia \\ ${ }^{2}$ School of Journalism and Communication, Jinan University, 510632, Guangzhou, China
}

\begin{abstract}
This study attempts to discover how multiculturalism interacts with sub-state nationalism as portrayed in the Malaysian top-grossing film of 2014 - The Journey directed by Chiu Keng Guan. The nature of Malaysian society and its colonial history might suggest that cultural interaction among its three major races (Malays, Chinese, and Indians) is a norm, but this study argues that the culture of these three major races as portrayed in the fictional film is made up of "systems of representations"; such systems of representations do not reflect the intentions of the subjects, but rather, actively construct meanings as conditions and instruments, signifying practice in reality. The application of in-depth interviews (e.g., the film director and the screenplay writer) discovered cultural identity depicted in the film as always having a specific 'positionality' within their representation, and the ideological struggle of multicultural nationalism embedded in the film is considered 'nonsubjective'. The authors believe that every culture is local, but no culture is autochthonous, and cultural identity illustrated in the film can be regarded as 'uniqueness of the soil'.
\end{abstract}

\section{Introduction and literature review}

The Journey represents something of a box office miracle, but the factual circumstances of Malaysian social, political, and historical nature is more meaningful for the authors of this study. According to the data given by the central government agency for the film industry of Malaysia - FINAS (The National Film Development Corporation Malaysia), the theatrical box-office earnings of the Malaysian Chinese-New-Year-celebration film The Journey (directed by Chiu Keng Guan) was 17,170,341.75 Malaysian Ringgit. It statistically assesses the success of this local film, as The Journey has become "the all-time top-grossing local film" [1]. The film director of The Journey believes that local Chinese filmmaking is promising, but still in its infancy. However, there is another factor: "... the Chinese overwhelmingly watch Hong Kong, Taiwanese and Mainland Chinese films; if not, they watch English-language films, but almost never films made in Bahasa Melayu; the same scenario occurs with Indian audiences; the situation with Malay audiences is more

* Corresponding author: jidayiming@163.com 
complex ... their first preference is for English-language films, followed by Indian films and only then films in Bahasa Melayu" [2]. The separation along ethnic lines is starkly drawn, and it also suggests that local cinema is a weak cultural force. Chiu, during the interview [1], interprets the audience composition for The Journey: there are only six million ethnic Chinese in Malaysia; deducting children and older adults, there are only three million potential Chinese cinemagoers; it would be impossible for this three million to give us seventeen million in box-office earnings. In other words, he meant that this film also successfully attracted a great number of non-ethnic Chinese. In this multi-ethnic country, "the filmmaker provides some illuminating insights into the relationship between film industry and Malaysia's multi-ethnic society" [3]. The Journey can be considered as an outstanding example.

The emergence of the multi-ethnic society invented by British colonial policy has resulted in today's Malaysian population being comprised of three major ethnic races: Malay, Chinese, and Indian. The great influx of Chinese into Malaya came after the midcentury had passed and was a result of the expansion of tin mining [4]. Then, another "large wave of newcomers again provide labour, this time for establishment of a new industry, rubber planting", and the "majority was Indians" [4]. In the 1990s, the term transnationalism was adopted to describe the links between these 'migrants' in places of settlement and origin and native communities. In their Ungrounded Empires : The Cultural Politics of Modern Chinese Transnationalism, Ong and Nonini stated that Chinese migrants developed a "third culture" in Malaysia, defined as a "modern Chinese transnationalism" that "provides alternative vision in late capitalism to Western modernity and generates new and distinctive social arrangements, cultural discourses, practices, and subjectivities" [5].

\subsection{Multiculturalism in Malaysia}

Multiculturalism is grounded in multi-sited dialogue among different peoples that result in trivial and nontrivial debates within Malaysia. Lian [6] argued that over the years consociational governments have evolved - more explicitly in Malaysia than in Singapore - that include power-sharing by the charter ethnic communities and the acknowledgement that resources should be distributed proportionate to the ethnic composition of the population [6]. He pointed out that, while consociation underlies the practice of multiculturalism in Malaysia, this is less apparent in Singapore [6]. "Notions of ethnicity and ethnic identity in Malaysia multicultural society are vital for galvanizing ethnic individuals to preserve, protect and promote their cultures, languages and religions, including their economic objectives" [7].

Multiculturalism has been historically embedded in Malaysian society and each of its states has had to manage this problem from the start. In a collection of literature, highlighting issues of migration and multiculturalism in Asia, Malaysia presents a dilemma. "By the 1990s, Malaysian ... multiculturalism had to respond to a changing world order" [8]. However, there is also a debate over millennial multiculturalism in Malaysia and its association with Asian forms of neoliberal multiculturalism. Malaysian society is characterized by what Nonini describes as 'imaginaries of desire in tension with cascades of symbolic violence' [9] across different cultural and institutional scales, where localizing and disciplining one group into a bounded place achieves the transnational mobility and power of another group.

Attention to the postcolonial nation-state of Malaysia in the international media frequently focuses on two apparently mutually contradictory areas. According to Goh and Holden, [8] "in economic terms, [Malaysia is] frequently praised as success stories of modernization", and "in cultural terms, [Malaysia is] is often seen as falling away from the 
principles of liberal democracy that are taken as representatives of modernity" [8]. The authors mean a way of thinking about race that examines differences between groups, aiming to understand and celebrate these differences, to also celebrate diversity. Chiu Keng Guan's The Journey coincided with a more general turn of celebrating diversity in Malaysian society, which saw his film enmeshed in a broader politics of cultural representation. The Journey was awarded "as '1-Malaysia' film" by Ahmad Shabery Cheek, the former minister of Communication and Multimedia of Malaysia. He regarded multi-racial actors for this film as an industrial phenomenon. Chiu Keng Guan measured Malaysian society with his eyes: randomly take a photo on the street showing different races naturally framed, and this is Malaysia. Considered together, this study is not only comparative across the three major races, but also raises important implications about the multiple ways of thinking, talking and performing race and multiculturalism within the society.

\subsection{Cultural identity and Malaysia's multicultural society}

Precisely because people construct their identities through discourse, they manifest their understanding of identity through detailed practices and formations at specific historical and institutional sites. The growing awareness of the concept of cultural citizenship embedded in constructions of national identities has emerged as an important analytic distinction in this study between native culture and accommodation to the dominant culture. According to Hall [9], identification is in the end conditional, lodged in contingency. The prevailing belief is that each race has its own culture, one's father-culture is the culture of one's race, and the culture does not obliterate differences [11]. However, another factor is dominance of Malay (Muslim) culture in this multicultural society. Not surprisingly, "it has ... served to accentuate the otherness of the non-Malays and to deepen their insecurity as minorities located within the hegemonic Malay scheme of things" [10]. Arguably, the dominant group - Malays - holds "their dominant position in the country". While complex ethnicities are equally applicable to Malaysia, there is no ambiguity or conflict about what the first local film was - the 1933 Malay-language film Laila Majnun. Ironically, the local Chinese film industry only began in 2010 [12]. Chiu believed that 2009 signified the opportune year for local Chinese film, following struggle, to create its own identity.

This study uses identity to explore the association between filmic society and 'deconstruction' and 'reconstruction' in terms of its 'historical, genealogical and discursive formations' [9] Hall stated that

"Identities are, as it were, the positions which the subject is obliged to take up while always 'knowing' (the language of consciousness here betrays us) that they are representations, that representation is always constructed across a 'lack', across a division, from the place of the Other, and thus can never be adequate-identical - to the subject process to a subject-position requires, not only that the subject is 'hailed', but that the subject invests in the position, means that suturing has to be thought of as an articulation, rather than a one-sided process, and that in turn places identification, if not identities, firmly on the theoretical agenda" [13].

Chiu [12] stated that, since 2010 in Malaysia, the kicks of Chinese-language film started at the hip with a slight knee bend; however the path was not smooth, while the roads were wet and slippery, uneven and rough. The success of The Journey is mostly credited for its "message for all Malaysian" [14]. It speaks to or hails Malaysian audiences into a place, which focalizes social subjects of particular discourses. Family is the basic unit of 
society. Therefore it stands to reason that anything connected to a family would connect with audiences. Chiu [12] figuratively added that the living circles of a Chinese family comprise the Malay and the Indian, and so does a Malay family's. His film provides the meeting point, the point of suture between the discourse of practices and the processes that produce subjectivities, "which construct us as subject which can be 'spoken"' [9-15].

\section{Objective of the study}

This study aims to investigate how multiculturalism interacts with sub-state nationalism portrayed in the 2014 Malaysian top-grossing film The Journey directed by Chiu Keng Guan. This study also inevitably gives attention to particular Malaysian cultural norms and nuances which nurture the local Chinese film industry.

\section{Methodology}

The in-depth interviews help the authors to understand the filmmakers' thoughts and explore relevant issue in depth. The purpose of in-depth interviewing is not to get answer to questions, but to understand the lived experience of filmmakers and the meaning they make of that experience. The author interviewed the film director - Chiu Keng Guan and the screenplay writer - Ryon Lee respectively at different times. Moreover, content analysis in this study involves drawing representative samples of content to measure or reflect differences in the content of multiculturalism and its association to filmic representation. On the basis of short description of content, interpretations and subjective valuejudgements are in ways, which make inter-subjectively valid assessment virtually impossible.

\section{Discussion}

In a country where the list of top-grossing films was dominated by tales of blood and guts (e.g., KL Gangster, 2011), the success of a film as subtle and personal as The Journey may signal a growing maturity among cinema-goers. The film, in Chinese dialects with smatterings of Malay and English, demonstrated the nature of a multi-language country. Hassan Abd Muthalib, the local film critic, argued that the popularity and record-breaking box-office earning "was because the film was conceived and made with honesty and sincerity - the vital ingredients for a story full of humanism" [11]. So-called 'humanism' is an important trigger, as cultural identity depicted in the film always represents a specific 'positionality', and the ideological struggle of multicultural nationalism embedded in the film is considered 'non-subjective'. In the interview, Chiu [11] expressed his own experience: "it was unexpected to have cinemagoers of other races though this is based upon a typical Chinese perspective; and ultimately, I was aware that no matter through which race's perspective, the story itself belongs to this country". Ryon Lee, the screenplay writer of The Journey, in the interview ${ }^{2}$, expressed a different opinion: Astro, the mainstream Malaysian media and entertainment holding company and producer of the film, invested in endless promotional slots, resulting in The Journey succeeding at the boxoffice. The authors believe that both the film's story and its promotional teaser appeal to a sense of humanism during the Chinese New Year. In discussing the films illustrated multiculturalism, we can understand civil groups, citizens, and foreign daughters-in-law portrayed as postcolonial actors. These social actors find themselves in an inextricable position in which they have no choice but to negotiate the colonial legacies of racialization and transform them into postcolonial multiculturalism. This film also directs the authors' 
attentions to the vernacular of cultural citizenship that articulates rights and differences. According to Rosaldo (2014), "cultural citizenship refers to the right to be different (in terms of race, ethnicity, or native language) with respect to the norms of the dominant national community, without compromising one's right to belong, in the sense of participating in the nation-state's democratic processes" [14].

Although the minister regards it as a good example of '1-Malaysia film', this does not mean the film illustrates events and characters in a manner of true harmony. Daniels [15] argued, "most Malaysians... evoking a conventional sense of togetherness, were convinced that their unity would withstand the scorching effect of economic and political crises". In the film, Uncle Chuan has a childhood friend who is a Malay woman. She had been one of his classmates and the story alludes to a possible (or imaginary) love relationship between her and Uncle Chuan. It is she who tells Benji about Uncle Chuan's birthday according to the Chinese Lunar calendar. It also subtly hints that when one race understands the culture of another race, there will be true understanding and tolerance. However, although the flashback scene of sending his daughter to study abroad seems touching, it implies educational issues. "In Malaysia, ... the Chinese population tends to have a greater financial ability to send their children to study overseas", and also, ethnic Chinese are "in a less favourable position to get a public university place due to their ethnicity" [16].

The nature of Malaysian society and its colonial history might suggest that cultural interaction among its three major races is a norm, but this study argues that the cultures of these three major races as portrayed in the fictional film is made up of "systems of representations", and such systems of representations do not reflect the intentions of the subjects, but rather actively construct meanings as conditions and instruments of real, significant practice. According to Chiu [12], amateur actors portray all of the friends Uncle Chuan meets while delivering his daughter's wedding invitation, and they give precise, perfect illustrations of real lifestyles in Malaysia. These may be conceived as the body of Malaysian multicultural nation: the agreement, in this case among the major races, about what the real relationship among social groups is about.

In his Malaysian Cinema in A Bottle, Hassan raised an important issue: can we hope for this in Malaysian cinema and celebrate it as something that unites us rather than divides us? Hassan criticised the industry phenomenon, as he believed difference races and different people have their own stories to tell and "we should be tolerant of stories that sometimes are difficult to comprehend or of truth that sometimes hurt" [17]. Also, what he highlights here is actually the way of identifying works of art. He is ideologically opposed to the view that works of arts can be identified "by race, language, culture or ethnicity even though there may be such subjectivities in the works" [17].

\section{Conclusion}

Above all, this study does not aim to discover the reasons why The Journey became the highest-theatrical-box-office-earning Malaysian-Chinese-language film. The cultural identities of the three major races portrayed in The Journey are within a system of representations, which express the nature of the ideological struggles of multicultural nationalism in the Malaysian context. Also, this film successfully demonstrates the negotiation of the colonial legacies of racialization. The family depicted in The Journey allows viewers to perceive the system of representations of ideology and cultural identity. Obviously, family is always the basic unit of society. Every culture is local, but no culture is autochthonous, and cultural identity illustrated in the film can be regarded as 'uniqueness of the soil'. 


\section{References}

1. S. K. Yan, The Star, (2014)

2. W. Van der Heide, Malaysian Cinema, Asian Film: Border Crossings and National Cultures. (Amsterdam University Press, Amsterdam, 2002).

3. R.W. Hefner, The Politics of Multiculturalism: Pluralism and Citizenship in Malaysia, Singapore, and Indonesia (University of Hawai'i Press, Honolulu, 2001)

4. J. A. Bakar, A Design Guide of Public Parks in Malaysia (Penerbit Universiti Teknologi Malaysia, Kuala Lumpur, 2002)

5. A. Ong, D. Nonini, Ungrounded Empires : The Cultural Politics of Modern Chinese Transnationalism (Routledge, New York, 1997)

6. K. F. Lian, Multiculturalism, Migration, and the Politics of Identity in Singapore. (Springer, Singapore, 2015)

7. H. Jamil, H. N. Ismail, Ethnicity and the State of Multiculturalism in Malaysia Education System, Intercultural and Multicultural Education : Enhancing Global Interconnectedness (Routledge, Oxon and New York, 2011)

8. D. P. S. Goh, M. Gabrielpillai, P. Holden, G. C. Khoo, Race and Multiculturalism in Malaysia and Singapore (Routledge, Oxon and New York, 2009)

9. S. Hall, Who Needs 'Identity'? Identity: A Reader, (Sage Publication Int, London, 2000)

10. D. C. L. Lim, Overcoming Passion for Race in Malaysia Cultural Studies (Brill, Danvers, 2008)

11. A. M. Hassan, the Journey by Chiu Keng Guan: A Message for All Malaysians, Astro Awani (2014)

12. This interview was conducted at one of the authors' - Wang Changsong's - office at the School of Communication, Universiti Sains Malaysia, in Penang, Malaysia, on 18 November 2015.

13. This interview was conducted by one of the authors - Wang Changsong - at the Han Chiang College campus field in Penang, Malaysia, on 5 February 2015

14. J. Clarke, K. Coll, E. Dagnino, Neveu, Disputing Citizenship (Policy Press, Clifton, 2014)

15. T. P. Daniels, Building Cultural Nationalism in Malaysia : Identity, Representation and Citizenship (Routledge, New York \& London, 2005)

16. T. W. W. Yuen, A. C. K. Cheung, A SWOT Analysis of Exporting Hong Kong's Higher Education to Asian Markets, Internationalization of Higher Education : The Case of Hong, (Springer, Singapore, 2016)

17. A. M. Hassan, Malaysian Cinema in A Bottle (Orange Dove, Selangor, 2013) 